PERSONAL PRACTICE

\title{
Managing obesity in secondary care: a personal practice
}

\author{
R Viner, D Nicholls
}

Arch Dis Child 2005;90:385-390. doi: 10.1136/adc.2004.062224

Obesity is becoming a common clinical headache for child health professionals, as the increase in professional and media concern has not been matched by effective clinical solutions. Added to this is considerable confusion about both the definitions of obesity and about which groups of children and adolescents actually require treatment. Little guidance exists for paediatricians and other child health specialists on the assessment and management of child and adolescent obesity. Guidelines produced by the American Academy of Pediatrics (AAP) are useful,' but require modification for non-American clinical practice. In the UK, the Royal College of Paediatrics and Child Health has recently issued excellent brief guidance on managing obesity in primary care, ${ }^{2}$ as has the Scottish Intercollegiate Guidelines Network. ${ }^{3}$

See end of article for authors' affiliations

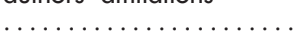

Correspondence to: Dr R Viner, Adolescent Medicine \& Endocrinology, Great Ormond Street Hospital, London WCIN 3JH, UK; R.Viner@ich.ucl.ac.uk

Accepted

1 September 2004
Q uality evidence on the best ways to treat childhood obesity is scarce. Dietetic interventions alone are unlikely to produce significant change. However, evidence from a recent US survey of paediatricians, nurses, and dieticians showed that dietetic interventions remained the mainstay of clinical practice, with few having access to child/adolescent weight management programmes or the time to address complex behavioural and medical issues within busy clinics. ${ }^{4}$ Many therefore turn to drugs to treat paediatric obesity, with little evidence to support use and no guidance on effective or appropriate prescribing. It is likely that child health professionals in the UK and elsewhere face similar problems.

We describe here the way we work with obese children and adolescents seen at Great Ormond Street Hospital and University College London Hospitals.

\section{WHEN TO BE CONCERNED \\ How to define obesity \\ We use the International Obesity Taskforce (IOTF) cut-offs to identify obesity, which are now marked on the new UK BMI charts and approximate the 99th BMI centile. As there is no accepted definition of extreme obesity, we regard those with a BMI of $\geqslant 3$ SD above the mean $(\geqslant 99.86$ th centile) as extremely obese and potentially high risk. We are beginning to use waist circumference as an additional indicator of potentially high risk abdominal obesity, as some national norms are now available.}

\section{Age of onset of obesity}

Early onset obesity (preschool) is a significant indicator of concern for a number of reasons. It is likely that duration of obesity in childhood is relevant to later cardiovascular risk, although the evidence for this is poor. More importantly, early onset severe obesity requires the exclusion of monogenic causes of obesity ${ }^{67}$ and consideration of major family function or parental mental health problems.

\section{ASSESSMENT}

We undertake assessments jointly in a multidisciplinary fashion. Detailed discussion of dietetic, exercise, and lifestyle assessments are beyond the scope of this article, although are obviously essential in terms of determining where change might best be focused: on food types or on portion sizes; on eating patterns and appetite regulation; on family eating habits and support; or on lifestyle and activity.

\section{Medical assessment}

There are three main aims of medical assessment: firstly, to categorise the child/adolescent in terms of their cardiovascular risk profile; secondly, to identify any current or potential complications of obesity; and thirdly, to exclude obesity secondary to endocrine or genetic causes. Treatment decisions in the overwhelming majority of cases will be based on the first two. The third aim, although laudable, rarely delivers in terms of diagnostic return, despite often becoming the sole focus of paediatric assessments of obesity.

\section{History and examination}

To fulfil these aims, we find it useful to supplement the standard paediatric history and examination as shown in tables 1 and 2. Normal growth rate virtually excludes endocrine causes for obesity; however table 3 outlines some useful indicators of secondary obesity.

\section{Assignment to categories for further assessment}

We find it useful to divide obese children and adolescents into five groups in order to make decisions on further investigation and treatment (see table 4). Recent analysis of data from our clinic showed that approximately one third (31\%) had the insulin resistance syndrome (IRS) as defined by having two or more of hypertension, dyslipidaemia, or abnormal glucose homoeostasis as well as obesity. We found that the risk of having the IRS was not related to BMI centile, pubertal status, or ethnicity, but that the syndrome was not present in children under 5 years. ${ }^{8}$ Because of this, our practice is to assess any obese child over the age of 5 years for 
Table 1 Important elements of history for childhood obesity

\begin{tabular}{|c|c|}
\hline & Questions \\
\hline A. Plot the "obesity trajectory" & $\begin{array}{l}\text { 1. Birth weight } \\
\text { 2. Early feeding history } \\
\text { 3. Whether onset of obesity was sudden or gradual and age of onset of obesity } \\
\text { 4. Whether progression of obesity was gradual or rapid } \\
\text { 5. Whether there have been any periods of very rapid weight gain, particularly recently } \\
\text { 6. Whether there have been any periods of weight loss (and why and how) } \\
\text { 7. Who else in the family is obese or has trouble controlling their weight }\end{array}$ \\
\hline B. Assess family risk profile & $\begin{array}{l}\text { To place the child in the appropriate risk category it is useful to ask about family history (in first and second } \\
\text { generations) of components of the insulin resistance syndrome, e.g.: } \\
\text { 1. Morbid obesity } \\
\text { 2. Type } 2 \text { diabetes } \\
\text { 3. Hypertension } \\
\text { 4. Dyslipidaemia } \\
\text { 5. Polycystic ovarian syndrome } \\
\text { 6. Early cardiovascular disease (defined as relatives who developed cardiovascular disease in the fifties or } \\
\text { earlier) }\end{array}$ \\
\hline C. Ethnicity & $\begin{array}{l}\text { Note the ethnic background of the child or adolescent, as those from a Black or South Asian background have a } \\
\text { higher risk of the insulin resistance syndrome and diabetes }\end{array}$ \\
\hline
\end{tabular}

the IRS. Liver function tests should be considered in all obese children, as non-alcoholic fatty liver disease (NAFLD) is increasingly recognised. ${ }^{9}$

\section{Psychological and behavioural assessment}

The purpose of a psychological assessment is to explore the child's and family's understanding about the problem of overweight, paving the way towards behavioural change, rather than to seek out underlying causes. Many parents are reluctant to draw attention to their child's overweight in the (correct) belief that this will increase the child's self consciousness in a way that may have negative consequences. Parental awareness of overweight is a risk factor for low self esteem. On the other hand, lack of parental awareness can mean that the issue is not addressed until problems arise.

\section{Family assessment}

In addition to diet and exercise, the family eating habits need to be explored, including the structure of mealtimes, who is present, conflict over food, food preparation, etc. Family attitude to overweight should include wider family such as grandparents, and also identify supportive figures. Parental obesity or eating disorders need to be enquired about directly, as they can be important in thinking about the type of intervention that is appropriate. Identification of other mental health difficulties in the family (for example, depression or substance abuse) is important in terms of the psychological risk they confer on the young person, and also may lead to consideration of possible neglect or abuse (see below). Finally, the impact of the problem on the family, and the level of support available to the young person in terms of getting to treatment, and family support and commitment to the lifestyle changes will also help to determine the appropriate intervention.

\section{School and peer relationships}

Peer rejection, teasing, and bullying are extremely high risk factors for psychopathology, and stigmatisation of obesity is sadly the rule, not the exception. Diet and exercise interventions will be ineffective if these issues are not addressed. The importance of supportive peer relationships becomes more important with age, most adolescents turning to peers before parents for support.

Table 2 Clinical examination

\begin{tabular}{|c|c|}
\hline & Signs and findings \\
\hline 1. Assessment of fat mass & $\begin{array}{l}\text { Accurate height and weight and waist circumference. We find other measures of fat mass (e.g. skinfold } \\
\text { thicknesses) are of little use in the clinical situation. Bioimpedance is becoming useful now that normative } \\
\text { data are available }\end{array}$ \\
\hline 2. Distribution of fat & $\begin{array}{l}\text { For example, whether generalised or abdominal or other pattern. The presence or absence of the "buffalo } \\
\text { hump" is a poor sign of Cushing's syndrome, as a prominent nuchal fat pad is common in simple obesity }\end{array}$ \\
\hline 3. Presence and degree of acanthosis nigricans & $\begin{array}{l}\text { Acanthosis nigricans, the presence of dark greasy thickening of the skin around the neck and in skin creases, } \\
\text { is suggestive of hyperinsulinism but is neither sensitive or specific }\end{array}$ \\
\hline 4. Accurate blood pressure & Using an appropriate size cuff (two readings, lying and sitting) \\
\hline 5. Pubertal and growth assessment & $\begin{array}{l}\text { Those obese before } 2 \text { years are tall for age. Many obese girls develop early in puberty. Pubertal and growth } \\
\text { assessment is particularly important to assess whether weight maintenance (i.e. growing into their weight) is } \\
\text { a viable option for treatment }\end{array}$ \\
\hline 6. Signs of hypothyroidism & Short stature, goitre, yellowish skin, dry skin and hair \\
\hline $\begin{array}{l}\text { 7. Signs of Cushing's syndrome or polycystic } \\
\text { ovarian syndrome (PCOS) }\end{array}$ & $\begin{array}{l}\text { Glucocorticoid and androgen excess in Cushing's syndrome produce striae, acne, telangiectasia, hirsutism, } \\
\text { and virilisation. The androgen excess in polycystic ovarian syndrome (PCOS) in girls produces hirsutism and } \\
\text { acne. However striae are almost universal in obese children and adolescence and we have not found that } \\
\text { the distribution or colour of the striae can help distinguish between the extremely common simple obesity } \\
\text { and the extremely rare Cushing's syndrome. Obesity by itself is practically never the presenting sign of } \\
\text { Cushing's syndrome }\end{array}$ \\
\hline 8. Signs of genetic obesity syndromes & $\begin{array}{l}\text { For example, Prader Willi, Bardet Biedl, leptin deficiency, melanocortin } 4 \text { receptor (MC4R) deficiency and } \\
\text { other monogenic forms of obesity. Monogenic forms of obesity remain a very rare cause of obesity in the } \\
\text { general population, although such syndrome should be considered in those who have very early onset of } \\
\text { extremely obesity. }{ }^{23} \text { See table } 3\end{array}$ \\
\hline
\end{tabular}




\begin{tabular}{|c|c|}
\hline & Clues to diagnosis \\
\hline $\begin{array}{l}\text { Cushing's } \\
\text { syndrome }\end{array}$ & $\begin{array}{l}\text { Distinctive clues } \\
\text { Short history of obesity (months rather than years) } \\
\text { Rapid height growth } \\
\text { Very rapid weight gain } \\
\text { Virilisation } \\
\text { Lack of family history of obesity } \\
\text { Overlap with simple obesity or PCOS (non- } \\
\text { distinctive clues) } \\
\text { Striae } \\
\text { Buffalo hump } \\
\text { Hypertension } \\
\text { Acne } \\
\text { Hirsutism }\end{array}$ \\
\hline $\begin{array}{l}\text { Prader-Willi } \\
\text { syndrome }\end{array}$ & $\begin{array}{l}\text { Distinctive clues } \\
\text { Hyperphagia } \\
\text { Learning difficulties } \\
\text { Small feet and hands } \\
\text { Neonatal hypotonia } \\
\text { Non-distinctive clues } \\
\text { Massive obesity } \\
\text { Hypogonadism. Note that apparent } \\
\text { hypogonadism is extremely common } \\
\text { in obese boys due to burying of the penis } \\
\text { in the perineal fat pad }\end{array}$ \\
\hline Leptin deficiency & $\begin{array}{l}\text { Distinctive clues } \\
\text { Nil } \\
\text { Non-distinctive clues } \\
\text { Early onset of massive obesity } \\
\text { Consanguineous parentage }\end{array}$ \\
\hline $\begin{array}{l}\text { Melanocortin } 4 \\
\text { receptor deficiency }\end{array}$ & $\begin{array}{l}\text { Distinctive signs } \\
\text { Nil } \\
\text { Non-distinctive clues } \\
\text { Early onset severe obesity } \\
\text { Hyperphagia }\end{array}$ \\
\hline
\end{tabular}

\section{Disordered eating and weight concerns}

Eating can be disordered in terms of either behaviour or beliefs and attitudes. Dietary restraint increases with increasing weight and can be beneficial in moderation. However, high levels of dietary restraint and emotional overeating can represent risk for the development of an eating disorder, particularly when associated with low self esteem and high body dissatisfaction. We use a clinical interview to identify eating disorders in obese children, as self-report questionnaires are useful only as screening tools. A comprehensive assessment for an eating disorder is indicated if there is strong parental suspicion, a history of rapid weight loss or gain, "yo-yo dieting", vomiting, or other attempts to counteract the fattening effects of food, or high weight concern and body dissatisfaction.

\section{Mood and self esteem}

Only about a third of patients with significant overweight have low self-worth, but where it is present it is often related to body dissatisfaction and weight concern. In routine practice, enquiring about the impact of the problem on the young person will usually identify social withdrawal, avoidance, tearfulness, and low mood when present. In cases of severe depression or suicidal behaviour the possibility of abuse of all types should be considered.

\section{Attitude to help and motivation to change}

Motivation and attitudes towards help are important predictors of engagement in treatment, which may in turn predict outcome. Assessment should include both the young person's and parent's expectations from treatment, what has been tried, what worked, what did not and why, and their previous experience of help. In practice most young people are motivated to lose weight, but motivation to undertake the changes necessary to achieve and maintain weight loss will vary from moment to moment, will depend on contextual factors such as mood or who is present in the room, and may be specific to certain behaviours, for example, motivated to change diet but not exercise.

We suggest to colleagues that referral for psychology or other child mental health assessment should be considered where there is evidence of emotional overeating or binge eating, depression or low self esteem, parental eating pathology, and other parental/family mental health concerns or abuse.

\section{TREATMENT}

\section{Assessment of risk and necessity of treatment}

The treatment options we offer are best guided by an assessment of risk in the medical and the psychological domains. Given the paucity of resources, we find it useful to prioritise subjects as shown in table 5 . Those high priority for treatment are those with additional components of the IRS $(\geqslant 2$ components), those with other medical problems (for example, obstructive sleep apnoea), and those in whom there are significant social or mental health concerns.

Outcome goals are set before treatment begins. Significant weight loss is extremely difficult to achieve and setting overambitious targets can be detrimental to motivation. Our primary aim in growing children is weight maintenance, thereby producing loss of overweight or reduction in BMI centile. ${ }^{10}$ This is obviously only achievable before the end of the pubertal growth spurt. Secondary aims depend on the clinical situation, and may include improvement in psychological wellbeing, family functioning and insulin sensitivity, liver function and lipids, etc.

\section{Treatment options}

We offer a range of treatment options to families, depending on their risk category (table 5) and other factors including patient preference, cognitive abilities, command of English, and geographical distance. Developmentally, adolescents have different concerns, levels of responsibility, and autonomy from children, and this might be relevant in the effectiveness of a particular treatment approach. The majority of treatment programmes are aimed at a broad age group centred around late childhood, and the paucity of programmes aimed specifically at adolescents has not been addressed. Our approach with adolescents puts greater emphasis on enhancing motivation in the young person and facilitating weight control, with parental support. With younger children parents need to be actively involved in making changes that may impact on the whole family. Adolescents may prefer to work individually, while children can be less self-conscious about discussing weight issues with peers in a group context. Further, although diet, exercise, behaviour modification, and other family based treatments appear to be the most appropriate approaches to the treatment of childhood obesity, it remains difficult to predict those who do and do not respond. "One size" does not fit all in obesity treatment!

\section{Goals of treatment}

\section{Standard treatment}

Standard treatment of childhood obesity has traditionally been referral to a dietician for advice on healthy eating. Subjects are generally seen monthly after assessment for a variable period to monitor adherence to diet and weight control. Regular contact with doctors or nutritionists in a dedicated obesity clinic can have a beneficial but small 
Table 4 Classification of obesity and plan of investigations

\begin{tabular}{|c|c|c|}
\hline & Definition & Investigations needed \\
\hline $\begin{array}{l}\text { A. Simple obesity with no family } \\
\text { history of IRS }\end{array}$ & $\begin{array}{l}\text { Obese but with no signs or symptoms suggestive } \\
\text { of secondary obesity or obesity complications }\end{array}$ & $\begin{array}{l}\text { Baseline bloods } \\
\text { Fasting glucose } \\
\text { Fasting insulin } \\
\text { Fasting lipids (total and HDL cholesterol, triglycerides) } \\
\text { Liver function (bilirubin and ALT) } \\
\text { Thyroid function (T4, TSH) } \\
\text { FBC, U\&E } \\
\text { Accurate blood pressure using an adequately large cuff. } \\
\text { Comparison to BP centiles for age and sex }\end{array}$ \\
\hline $\begin{array}{l}\text { B. Simple obesity with family } \\
\text { history or signs of IRS }\end{array}$ & $\begin{array}{l}\text { Obese with acanthosis nigricans or family } \\
\text { history of IRS }\end{array}$ & $\begin{array}{l}\text { Oral glucose tolerance test } \\
\text { Baseline bloods as above } \\
\text { Blood pressure }\end{array}$ \\
\hline $\begin{array}{l}\text { C. Marked abdominal obesity, } \\
\text { with or without family history of IRS }\end{array}$ & & Bloods as per (B) \\
\hline D. Extreme obesity & BMl z score $\geqslant 3.0$ & $\begin{array}{l}\text { Bloods as per (B) plus DNA screening for monogenic forms of } \\
\text { obesity (if onset }<5 \text { years) } \\
\text { Sleep study for obstructive sleep apnoea if significant symptoms } \\
\text { (snoring, difficult to wake, nightmares, daytime somnolence) }\end{array}$ \\
\hline E. Suspected secondary obesity & $\begin{array}{l}\text { Signs or symptoms suggestive of secondary } \\
\text { obesity }\end{array}$ & $\begin{array}{l}\text { Bloods as per (B) plus } \\
\text { Karyotype } \\
\text { Midnight and } 8 \text { am cortisol } \\
\text { Referral to endocrinologist or geneticist as appropriate }\end{array}$ \\
\hline
\end{tabular}

impact on weight; ${ }^{11}$ however such approaches have very poor long term results. ${ }^{12}$ We use this approach only where children or their parents are unable or unwilling to enter a weight control programme.

\section{Multidisciplinary weight control programme}

There is limited quality data on the necessary components of programmes to treat childhood obesity. ${ }^{13}$ Most specialists advocate a multidisciplinary approach to childhood obesity which includes interventions aimed at producing long term behavioural change. Effective behavioural programmes usually include the following features:

- Family based (direct involvement of at least one parent)

- Nutritional and exercise advice

- Behavioural components, including self-monitoring, modelling, goal setting, stimulus control, reinforcement

- Decreasing sedentary activities, increasing lifestyle activity

- Social support.

There are a number of specific multi-component treatment approaches, the best evaluated of which is the Epstein's family based behavioural treatment (FBBT), ${ }^{14}$ also known as the "traffic light diet" because of its child friendly approach to categorising foods into red (stop), yellow (slow down), and green (go). Aimed at mid-school/early adolescent children, we have found the approach can be modified for a UK clinic population of mixed class and ethnicity and with varying degrees of overweight. We have found the programme results in a mean loss of $0.2 \mathrm{SD}$ in $\mathrm{BMI} ;{ }^{15}$ however the approach needs further evaluation to establish effectiveness. For older adolescents, Dr Deborah Christie at the Middlesex Adolescent Unit has adapted the approach of Braet $^{16}$ which argues against prescribed dietary restriction but rather emphasises the development of self efficacy skills aimed at weight control, to develop the HELP programme (healthy eating and lifestyle plan).

Both approaches aim to change eating behaviours and influence environmental factors, using child and adolescent friendly motivational approaches. The young people choose their own goals and rewards, learn coping and problem solving, and through self monitoring, learn to identify internal and external factors likely to trigger relapse. In addition to the role of parents in offering positive reinforcement (for example, through contractual agreements, stickers for successes, verbal support, and compliments within the family), behaviour modification that also involves parents along with weight reduction or maintenance techniques is recommended as ideal. ${ }^{17}$

Table 5 Assessment of risk and treatment options

\begin{tabular}{lll}
\hline Category & Definitions & Treatment \\
\hline Low risk & $\begin{array}{l}\text { No significant psychological concerns } \\
\text { Does not have IRS or other medical complications of obesity }\end{array}$ & Multidisciplinary group weight management programme \\
Medium risk & $\begin{array}{l}\text { Either of: } \\
\text { Insulin resistance syndrome ( } \geqslant 2 \text { additional components) } \\
\text { Significant psychological concerns }\end{array}$ & $\begin{array}{l}\text { Multidisciplinary group remains primary treatment. } \\
\text { Consider use of metformin for insulin resistance } \\
\text { Consider mental health input for child and parents }\end{array}$ \\
High risk & $\begin{array}{l}\text { Sleep apnoea syndrome } \\
\text { Type 2 diabetes } \\
\text { Child protection concerns }\end{array}$ & $\begin{array}{l}\text { Medical treatment as appropriate. } \\
\text { Mental health treatment for child and family } \\
\end{array}$ \\
\hline
\end{tabular}




\section{Drug treatment}

Drug treatment has traditionally not been considered an option in childhood obesity; however the lack of effectiveness of other treatments has prompted a reconsideration of more intensive treatments, including drug treatment in those with significant morbidity. ${ }^{18}$ There are no drugs present approved in the UK or USA for the treatment of obesity in childhood. Drugs we have found helpful in a small number of patients include metformin and orlistat.

\section{Metformin}

Metformin increases sensitivity to insulin at both hepatic and peripheral levels, and has been used in obese adolescents with the aim of both encouraging weight loss and reducing progression to type 2 diabetes. ${ }^{19}$ Trials have shown that doses up to $2 \mathrm{~g}$ per day are safe and well tolerated in obese adolescents ${ }^{20}$ and that small degrees of weight loss (up to 5\%) can be expected. ${ }^{19}$ We have found metformin at a dose of $500 \mathrm{mg}-1 \mathrm{~g}$ twice daily useful as a second line treatment (after weight control programmes) in those who have marked hyperinsulinaemia.

\section{Orlistat}

Of those drugs used for weight loss in adults, the only presently realistic option in children and adolescents is orlistat (Xenical). Orlistat works by reducing fat absorption by binding lipase in the intestinal lumen. As up to one third of dietary fat is then excreted in the stools, patients must adhere to a very low fat diet or face extremely unpleasant gastrointestinal side effects. This results in a "catch 22 " situation: to tolerate orlistat requires high adherence to a low fat diet; however, if one can adhere to a low fat diet, orlistat is not required! Other potential side effects include deficiency of fat soluble vitamins; supplementation of vitamins A, D, E, and K must be undertaken with orlistat. ${ }^{21}$ A pilot study has found that orlistat is reasonably well tolerated in adolescents over three months, ${ }^{22}$ but randomised evidence of its effectiveness in this age group has not yet been published. We have used orlistat in only a few patients with very limited success.

\section{Sibutramine}

Sibutramine is a noradrenaline and serotonin reuptake inhibitor that works primarily through appetite suppression and has proved highly effective in adult obesity. There remain significant concerns about its use in children and adolescents and we have no experience with it in our patients.

\section{Follow up}

With emphasis on small changes that endure, trends in weight loss (or gain) and the effects of intervention can only be seen over time. Long term success is possible given supportive parents and a motivated child, and the need for the family to seek ongoing support should be emphasised throughout. As mentioned, weight loss of as little as $5-10 \%$ results in significant improvement in cholesterol, blood pressure, and blood glucose.

\section{Child protection and obesity}

Much has been made recently of the potential for parental inaction on obesity to be regarded as an issue of child protection on the grounds of neglect or emotional abuse. Neglected children are nine times more likely to become obese, and adults seeking treatment for obesity are four times more likely to have experienced sexual abuse, and twice as likely to experience neglect. It does not follow however, that obesity must represent family dysfunction of some kind. We believe that the presence of obesity itself is not grounds for child protection action per se, but rather that obesity may be one of many signs of neglect/emotional abuse. Where child protection issues are suspected we would expect to find evidence in other aspects of care (in the case of neglect) or in family relationships and child mental health (in the case of emotional, physical, and sexual abuse). It is also important to remember that obesity remains extremely difficult for professionals to treat, thus criticising parents for what professionals are frequently unable to do smacks of hypocrisy. As with any other chronic illness, child protection concerns may arise when parents either actively subvert treatment or fail to appreciate the risks of non-treatment.

\section{RESOURCES}

- Gibson P, Edmunds L, Haslam DW, et al. An approach to weight management in children and adolescents (2-18 years) in primary care. London: Royal College of Paediatrics, 2002. Available from the Royal College of Paediatrics and Child Health (www.rcpch.ac.uk).

- Scottish Intercollegiate Guidelines Network (SIGN). Management of obesity in children and young people: a national clinical guideline. Edinburgh: SIGN, Royal College of Physicians, 2003 (www.sign.ac.uk).

- BMI centile charts based on the UK 1990 Growth Reference and Waist centile charts are available from the Child Growth Foundation, 2 Mayfield Avenue, London W4 IPW or from Harlow Printing, Maxwell St, South Shields, NE33 4PU, UK (www.harlowprinting.co.uk).

\section{ACKNOWLEDGEMENTS}

We would like to thank Deborah Christie, Peter Hindmarsh, Jane Wardle, and Carolyn Edwards.

\section{Authors' affiliations}

R Viner, Adolescent Medicine \& Endocrinology, Great Ormond Street Hospital, London, and UCL Hospitals, London, UK

D Nicholls, Feeding and Eating Disorders Service, Great Ormond Street Hospital, London, UK

Competing interests: none declared

\section{REFERENCES}

1 Barlow SE, Dietz WH. Obesity evaluation and treatment: Expert Committee Recommendations. Pediatrics 2002;102:e29.

2 Gibson P, Edmunds L, Haslam DW, et al. An approach to weight management in children and adolescents (2-18 years) in primary care. London: Royal College of Paediatrics, 2002.

3 Scottish Intercollegiate Guidelines Network (SIGN). Management of obesity in children and young people: a national clinical guideline. Edinburgh: SIGN, Royal College of Physicians, 2003.

4 Barlow SE, Trowbridge FL, Klish WJ, et al. Treatment of child and adolescent obesity: reports from pediatricians, pediatric nurse practitioners and registered dieticians. Pediatrics 2002;110:229-35.

5 McCarthy HD, Ellis SM, Cole TJ. Central overweight and obesity in British youth aged 11-16 years: cross sectional surveys of waist circumference. BMJ 2003;326:624.

6 Farooqi IS, O'Rahilly S. Recent advances in the genetics of severe childhood obesity. Arch Dis Child 2000;83:31-4.

7 Montague CT, Farooqi IS, Whitehead JP, et al. Congenital leptin deficiency is associated with severe early-onset obesity in humans. Nature 1997;387:903-8.

8 Viner RM, Segal TY, Lichtarowicz-Krynska E, et al. Prevalence of the insulin resistance syndrome in obesity. Arch Dis Child 2005;90:10-14.

9 Marion AW, Baker AJ, Dhawan A. Fatty liver disease in children. Arch Dis Child 2004;89:648-52.

10 Viner R, Bryant-Waugh R, Nicholls D, et al. Childhood obesity. Aim should be weight maintenance, not loss. BMJ 2000;320:1401-3.

11 Sabin MA, Crowne E, Shield JHP. Outpatient-based paediatric obesity intervention clinic-simple advice and support are associated with significant reductions in weight in the first year. Arch Dis Child 2003;88(suppl 1):A66-7.

12 Pinelli L, Elerdini N, Faith MS, et al. Childhood obesity: results of a multicenter study of obesity treatment in Italy. J Pediatr Endocrinol Metab 1999; 12:795-9.

13 Summerbell CD, Ashton V, Campbell KJ, et al. Interventions for treating obesity in children. Cochrane Database Syst Rev 2003:CD001872.

14 Epstein LH. Family-based behavioural intervention for obese children. Int J Obes Relat Metab Disord 1996;20(suppl 1):S14-21.

15 Nicholls D, Edwards C, Cooke L, et al. Outcome of family based behaviour therapy for obesity: pilot data. Arch Dis Child 2004;89(suppl 1):A56. 
16 Braet C. Treatment of obese children: a new rationale. Clin Child Psychol Psychiatry 1999;4:579-91.

17 Wrotniak BH, Epstein LH, Paluch RA, et al. Parent weight change as a predictor of child weight change in family-based behavioral obesity treatment Arch Pediatr Adolesc Med 2004:158:342-7.

18 Saelens BE, Daniels SR. Child obesity: causes and therapies. Curr Opin Endocrinol Diabetes 2003;10:3-8.

19 Freemark M, Bursey D. The effects of metformin on body mass index and glucose tolerance in obese adolescents with fasting hyperinsulinemia and a family history of type 2 diabetes. Pediatrics $2001 ; 107:$ e55
20 Jones KL, Arslanian S, Peterokova VA, et al. Effect of metformin in pediatric patients with type 2 diabetes: a randomized controlled trial. Diabetes Care 2002;25:89-94.

21 McDuffie JR, Calis KA, Booth SL, et al. Effects of orlistat on fat-soluble vitamins in obese adolescents. Pharmacotherapy 2002;22:814-22.

22 McDuffie JR, Calis KA, Uwaifo Gl, et al. Three-month tolerability of orlistat in adolescents with obesity-related comorbid conditions. Obes Res 2002; 10:642-50.

23 Farooqi IS, Keogh JM, Yeo GS, et al. Clinical spectrum of obesity and mutations in the melanocortin 4 receptor gene. N Engl J Med 2003;348: 1085-95

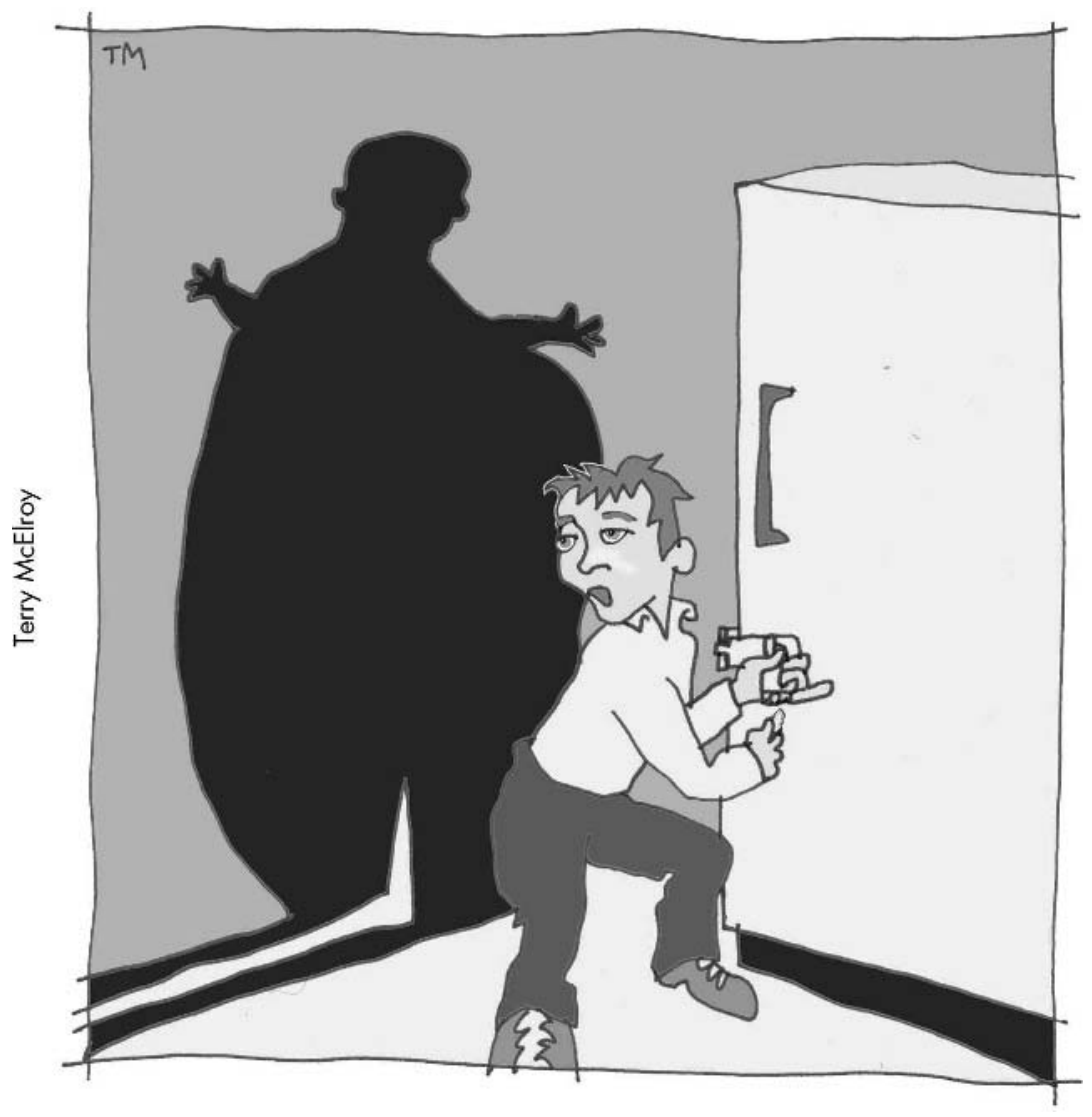

